ISSN: 2224-0616

Int. J. Agril. Res. Innov. Tech. 10(1): 87-93, June 2020

DOI: https://doi.org/10.3329/ijarit.v10i1.48098
OPEN 2 ACCESS

Available online at https://ijarit.webs.com https://www.banglajol.info/index.php/IJARIT

\title{
Floating gardening in Bangladesh: a sustainable income generating activity in wetland areas
}

\author{
H. Bala ${ }^{1}$, A.K. Ghosh ${ }^{1}$, M.M.H. Kazal ${ }^{1}$, M.S. Rahman ${ }^{2}$, M. Sultana ${ }^{3}$ and M.H.K. Sujan ${ }^{1 *}$ \\ Received 17 April 2020, Revised 17 May 2020, Accepted 20 June 2020, Published online 30 June 2020
}

\section{A B S T R A C T}

Floating gardening acts as a fruitful climate-change adaptation strategy in different wetland areas of Bangladesh. The study accomplished to examine the profitability of floating gardening in Gopalgonj district of Bangladesh in 2018. A total of 100 floating gardeners were interviewed to achieve the objectives. Descriptive statistics and Cobb-Douglas production function were used to investigate the factors influencing yield of floating gardening. The findings reveal that, small and marginal farmers were more involved in floating gardening. Around sixty-five percent of the production costs was contributed by human labour. Floating gardeners of the study area earned a net return of BDT 457,901 per hectare per year. Human labour, fertilizers and support materials significantly affected the yield. More training and improved marketing system could further enhance the profitability.

Keywords: Adaptation strategy, Climate change, Cobb-Douglas production function, Income, Profitability.

\footnotetext{
${ }^{I}$ Dept. of Development and Poverty Studies, Sher-e-Bangla Agricultural University, Dhaka, Bangladesh.

${ }^{2}$ Dept. of Management and Finance, Sher-e-Bangla Agricultural University, Dhaka, Bangladesh.

${ }^{3}$ Dept. of Agricultural Economics, Sher-e-Bangla Agricultural University, Dhaka, Bangladesh.
}

*Corresponding author's email: mhksujan@gmail.com (M.H.K. Sujan)

Cite this article as: Bala, H., Ghosh, A.K., Kazal, M.M.H., Rahman, M.S., Sultana, M. and Sujan, M.H.K. 2020. Floating gardening in Bangladesh: a sustainable income generating activity in wetland areas. Int. J. Agril. Res. Innov. Tech. 10(1) 87-93. https://doi.org/10.3329/ijarit.v10i1.48098

\section{Introduction}

Climate change bring up a significant change in the agricultural practices of the low laying and flood prone areas of Bangladesh (Ahmed, 2006; Brouwer et al., 2007; Awal, 2014; Islam et al., 2015b). Due to these changes, some parts of the country remain waterlogged for a prolonged period. To overcome this problem, farmers in these areas are adopting alternative cultivation techniques (Sen and Zaid, 2010; Pavel et al., 2013; Hoque et al., 2016; Chowdhury and Moore, 2017; Islam et al., 2019; Kabir et al., 2019; Kabir et al., 2020). Floating gardening is one of the techniques where plants are grown on a bio-land or floating bed of water hyacinth, algae or plant residues (Winterborne, 2005; Saha, 2010; Alam and Chowdhury, 2018; Islam et al., 2019). It is being practiced in southern floodplains of Bangladesh, particularly in the Barishal, Gopalganj and Pirojpur district (Haq and Nawaz, 2009; Chowdhury and Moore, 2017; Islam et al., 2019). Irfanullah et al. (2011) studied the contribution of this practice to rebuild life after devastating flood in northern Bangladesh and found its positive impacts on nutritional security, household income and land-use capacity.
Chowdhury and Moore (2017) also investigated the possibilities of this practice as a technique for climate change adaptation. Several other studies also recorded the success of this practice in coastal areas as well as wetland areas of the country (Byomkesh et al., 2008; IUCN, 2008; Saha, 2010; Irfanullah, 2013; Hasan et al., 2017). Kabir et al. (2019) studied the cost-benefit of seedling production on floating beds in Pirojpur district of Bangladesh and found a positive income with BCR 1.43. Islam et al. (2019) identified the constraints of floating gardening in wetland (haor) area of the country. However, financial profitability studies are very limited. Adoption of any new technology depends on its profitability. Profitability, factors affecting yield and constraints of this practice were investigated in this study. The adverse effect of climate change forces the policy maker to take newer production approaches to ensure food security for the marginalized people. Result of this study will be a handy tool to the policy maker, agricultural extension worker and development worker to take necessary steps for ensuring sustainable agricultural production. 


\section{Methodology}

\section{Data sources}

The study was conducted in Gopalgonj district of southern Bangladesh due to availability of floating gardens. A list of floating gardeners of the district was prepared, which served as sampling framework of the work. A total of 100 floating gardeners were selected randomly from the list for face-to-face interview. Respondents were then grouped into marginal (0.02 - 0.20 hectare), small (0.20 - 1.00 hectare), and medium (1.00 3.00 hectare) farmer category based on the classification of DAE (1999). Data on the characteristics of the respondent, floating gardening activities, input use pattern, cost of inputs, output price, and constraint of floating gardening were collected using pre-tested interview schedule during January to June 2018.

\section{Analytical techniques}

Collected data were analyzed by using both descriptive and inferential statistics. Descriptive statistics like mean, and percentage were used to investigate socio-economic status of the floating gardeners. Profitability of floating gardening was estimated by using following formula as like Sujan et al., 2017a \& b:

$\mathrm{GR}_{\mathrm{i}}=\sum_{\mathrm{i}=1}^{\mathrm{n}} \mathrm{Q}_{\mathrm{ij}} \mathrm{P}_{\mathrm{ij}}$

Where, $\mathrm{GR}_{\mathrm{i}}=$ Gross return of $\mathrm{i}^{\text {th }}$ gardener; $\mathrm{Q}_{\mathrm{ij}}=$ Quantity of $j^{\text {th }}$ product of $i^{\text {th }}$ gardener; $P_{i j}=$ Price of $j^{\text {th }}$ product of $i^{\text {th }}$ gardener; $i=1,2,3 \ldots . n$.

Net return was calculated by deducting all costs from the gross return. To estimate the net return of floating gardening following formula was used:

$\pi_{\mathrm{i}}=\mathrm{GR}_{\mathrm{i}}-\sum_{\mathrm{i}=1}^{\mathrm{n}} \mathrm{P}_{\mathrm{ij}} \mathrm{X}_{\mathrm{ij}}-\mathrm{TFC}_{\mathrm{i}}$

Where, $\pi_{\mathrm{i}}=$ Net return of $\mathrm{i}^{\text {th }}$ gardener; $\mathrm{GR}_{\mathrm{i}}=$ Gross return of $i^{\text {th }}$ gardener; $P_{i j}=$ Price of $j^{\text {th }}$ input of $i^{\text {th }}$ gardener; $X_{i j}=$ Quantity of $j^{\text {th }}$ input of $i^{\text {th }}$ gardener; $\mathrm{TFC}_{\mathrm{i}}=$ Total fixed cost of $\mathrm{i}^{\text {th }}$ gardener; $\mathrm{i}$ $=1,2,3, \ldots \ldots . . . \mathrm{n}$.

Inferential statistics was applied to explore the factors affecting the yield of floating gardening. Cobb-Douglas production function was used to estimate these factors' influence. This function was used because of its mathematical properties, ease of interpretation and conceptual simplicity.
It is the most widely used model for fitting agricultural production data (Heady and Dillon, 1961). It is also relatively easy to estimate because in logarithmic form it is linear and parsimonious (Beattie and Taylor, 1985). The functional form of the Cobb-Douglas production function was as follows:

$\mathrm{Y}=\mathrm{AX}_{1}{ }_{1}{ }_{1} \mathrm{X}_{2}{ }^{\beta_{2}}$

The empirical production function for this research was the following:

$\ln Y=\alpha+\beta_{1} \ln X_{1}+\beta_{2} \ln X_{2}+\beta_{3} \ln X_{3}+\beta_{4}$ $\ln \mathrm{X}_{4}+\beta_{5} \ln \mathrm{X}_{5}+\mathrm{U}_{\mathrm{i}}$

Where, $\mathrm{Y}=$ Yield $\left(\mathrm{kg} \mathrm{ha}^{-1}\right) ; \mathrm{X}_{1}=$ Human Labor $\left(\right.$ man-days ha-1); $\mathrm{X}_{2}=$ Seed $\left(\mathrm{kg} \mathrm{ha} \mathrm{k}^{-1}\right) ; \mathrm{X}_{3}=$ Fertilizer $\left(\mathrm{kg} \mathrm{ha}^{-1}\right) ; \mathrm{X}_{4}=$ Insecticides \& Pesticides $\left(\mathrm{kg} \mathrm{ha}^{-1}\right) ; \mathrm{X}_{5}=$ Support material $\left(\right.$ BDT ha $\left.^{-1}\right) ; \alpha=$ Intercept; $\beta_{1}, \beta_{2}$---- $\beta_{5}=$ Coefficients of the respective variables to be estimated; and $\mathrm{U}_{\mathrm{i}}=$ Error term.

\section{Results and Discussion}

\section{Socio-economic profile of farmers}

Demographic statistics (Table 1) reveals that about $54 \%$ of the floating gardeners were middle aged (35-50). Similar to the findings of Pavel et al. (2014) and Kabir et al. (2019), about 68\% of the respondents was found literate. It indicates that floating gardeners were educated. Middle aged and literate people's greater tendency to adopt with unconventional technologies might be the reason behind their more involvement in this practice. Average marginal, small and medium farm size was $0.16,0.73$ and 1.27 hectare, respectively. More involvement of marginal (21\%) and small farmers (56\%) in floating gardening signifies the importance of this practice as an alternative source of income to them (Alam and Chowdhury, 2018; Kabir et al., 2019). Analysis of the housing pattern also reveals a typical scenario of resource poor people (Irfanullah, 2009). Though sanitation facilities were satisfactory, concerns about taking nutritious food were not up to the mark (Chowdhury and Moore, 2017). A majority $(69 \%)$ of the respondent opined that their household income from floating gardening was about BDT 0.5 to BDT 1.0 lac per year. It also reveals the poor condition of the people engaged with floating gardening. Pavel et al. (2014) found an incremental income of the floating gardeners in Sunamganj haor of Bangladesh. In the study area, fifty-eight percent respondents use their own fund for floating gardening whereas $34 \%$ 
collect loan from bank and NGOs. This result is in investment for floating gardening might be the the line with the result found by MoEF (2005) responsible factor for that pattern of resource and Hasan et al. (2017). Requirement of lower allocation.

Table 1. Socio-economic profile of the floating gardeners of the study area.

\begin{tabular}{|c|c|c|c|}
\hline Attributes & Unit & Categories & Percentage (\%) \\
\hline \multirow[t]{3}{*}{ Age of respondent } & \multirow[t]{3}{*}{ Year } & Young age (<35 years) & 20 \\
\hline & & Middle age ( $35-50$ years) & 54 \\
\hline & & Old age ( $>50$ years) & 26 \\
\hline \multirow[t]{5}{*}{ Educational status } & \multirow[t]{5}{*}{ Year } & Illiterate (<1 years) & 32 \\
\hline & & Primary (1-5 years) & 37 \\
\hline & & Secondary (6-10 years) & 17 \\
\hline & & Higher secondary (11-12 years) & 10 \\
\hline & & Above higher secondary (>12 years) & 4 \\
\hline \multirow[t]{4}{*}{ Land ownership status } & \multirow[t]{4}{*}{ Hectare } & Marginal farmer (0.02-0.20 hectare) & 21 \\
\hline & & Small farmer (0.20-1.0o hectare) & 56 \\
\hline & & Medium farmer (1.00-3.0o hectare) & 23 \\
\hline & & Large farmer (> 3.00 hectare $)$ & 0 \\
\hline \multirow[t]{3}{*}{ Pattern of housing } & \multirow[t]{3}{*}{-} & Tin shade/mud made & 24 \\
\hline & & Semi pukka & 44 \\
\hline & & Pukka & 32 \\
\hline \multirow{4}{*}{$\begin{array}{l}\text { Perception regarding food } \\
\text { intake }\end{array}$} & \multirow[t]{4}{*}{-} & Not worried about nutrition & 15 \\
\hline & & Poor nutritious & 2 \\
\hline & & Partial-nutritious & 31 \\
\hline & & Nutritious & 52 \\
\hline \multirow[t]{3}{*}{ Sanitation status } & \multirow[t]{3}{*}{-} & Use of open space & 0 \\
\hline & & Use of healthy toilet & 79 \\
\hline & & Use of modern toilet & 21 \\
\hline \multirow{3}{*}{$\begin{array}{l}\text { Perceived income from } \\
\text { floating gardening }\end{array}$} & \multirow[t]{3}{*}{ BDTb } & Less than 0.5 lac & 17 \\
\hline & & From 0.5 to 1.0 lac & 69 \\
\hline & & Greater than 1.0 lac & 14 \\
\hline \multirow{4}{*}{$\begin{array}{l}\text { Sources of capital for } \\
\text { gardening }\end{array}$} & \multirow[t]{4}{*}{ - } & Own fund & 58 \\
\hline & & Bank loan & 12 \\
\hline & & NGO loan & 22 \\
\hline & & Money lender & 8 \\
\hline
\end{tabular}

${ }^{a} 1$ hectare $=247$ decimal; ${ }^{b} 1$ USD $=85$ BDT

\section{Input use pattern in floating gardening}

Human labour requirement per hectare was 932 man-days per year (Table 2) of which around 61 percent was family supplied. Smaller farm size and poor people's greater involvement might be the reason for higher employment of family labour in this practice. Average cost of seed or seedling was BDT 10,964 per hectare. Per hectare average cost for support materials was BDT 94,795. These support materials were used during the preparation of floating beds. That's why a significant portion (16.5\%) of the required resource goes to manage support materials for floating gardening (Table 3 ).

Table 2. Input use pattern in floating gardening practices (per year).

\begin{tabular}{|c|c|c|c|c|c|}
\hline Items & Units & $\begin{array}{l}\text { Marginal } \\
\text { farmer }\end{array}$ & $\begin{array}{c}\text { Small } \\
\text { farmer }\end{array}$ & $\begin{array}{l}\text { Medium } \\
\text { farmer }\end{array}$ & Average \\
\hline Human labour & Man-days ha-1 & 880 & 939 & 964 & 932 \\
\hline Family labour & Man-days ha-1 & 606 & 568 & 519 & 565 \\
\hline Hired labour & Man-days ha-1 & 274 & 371 & 445 & 367 \\
\hline Seed or Seedling & BDT ha-1 $^{-1}$ & 10,378 & 11,120 & 11,120 & 10,964 \\
\hline Fertilizers & $\mathrm{Kg} \mathrm{ha}^{-1}$ & 267 & 284 & 297 & 284 \\
\hline Insecticides \& Pesticides & Bottles ha' & 30 & 27 & 32 & 30 \\
\hline Support materials & BDT ha-1 $^{-1}$ & 90,809 & 95,134 & 97,605 & 94,795 \\
\hline
\end{tabular}


Average use of fertilizers was $284 \mathrm{~kg} \mathrm{ha}^{-1}$. The proportional investment on seed/seedling, fertilizers and insecticides \& pesticides were very low (Islam and Atkins, 2007; Irfanullah, 2009; Chowdhury and Moore, 2017) although Hasan et al. (2017) and Islam et al. (2019) claimed about no use of chemical fertilizers for floating gardening. The smart use of different organic matters and required essential nutrients for the plants during floating beds preparation might confirm the expected growth of the plants. That's why farmers might be reluctant to use additional chemical fertilizers.

\section{Cost of production on floating gardening practices}

Maximum proportion (around 65\%) of costs for human labour indicates the labour intensive nature of this practice and implies that smallholder or marginalized people can manage their own work by engaging themselves in floating gardening (MoEF, 2005; Irfanullah et al., 2007; Islam and Atkins, 2007; Irfanullah et al., 2011). Incremental allocation of family labour with the decreasing amount of land ownership also signifies the importance of this practice as an income-generating source to the landless or marginal people (Pavel et al., 2014; Chowdhury and Moore, 2017). About $87 \%$ of the total costs of production were contributed by variable costs of which $16.5 \%$ of the costs was incurred for the preparation of support materials. Greater involvement of family supplied and higher lanour and lower necessity of fixed investment in this practice might be the reason for higher requirement of variable costs.

Table 3. Cost of production on floating gardening practices (per year).

\begin{tabular}{|lcccc|}
\hline Items & $\begin{array}{c}\text { Marginal farmer } \\
\left(\mathrm{BDT}^{-1}\right)\end{array}$ & $\begin{array}{c}\text { Small farmer } \\
\left(\mathrm{BDT} \mathrm{ha}^{-1}\right)\end{array}$ & $\begin{array}{c}\text { Medium farmer } \\
\left(\mathrm{BDT} \mathrm{ha}^{-1}\right)\end{array}$ & Average \\
\hline A. Variable cost & $474,407(86.8)$ & $502,601(87.0)$ & $517,551(87.1)$ & $500,118(87.0)$ \\
\hline Human labour & $351,870(64.4)$ & $375,592(65.0)$ & $385,476(64.9)$ & $372,883(64.9)$ \\
\hline Hired labour & $109,712(20.1)$ & $148,260(25.7)$ & $177,912(30.0)$ & $146,985(25.6)$ \\
\hline Family labour & $242,158(44.3)$ & $227,332(39.4)$ & $207,564(34.9)$ & $225,899(39.3)$ \\
\hline Seed or Seedling & $10,378(1.9)$ & $10,872(1.9)$ & $11,120(1.9)$ & $10,825(1.9)$ \\
\hline Fertilizers & $8,006(1.5)$ & $8,525(1.5)$ & $8,896(1.5)$ & $8,501(1.5)$ \\
\hline Insecticides \& & $13,343(2.4)$ & $12,479(2.2)$ & $14,455(2.4)$ & $13,115(2.3)$ \\
\hline Pesticides & & & & \\
\hline Support materials & $90,809(16.6)$ & $95,134(16.5)$ & $97,605(16.4)$ & $94,794(16.5)$ \\
\hline B. Fixed cost & $72,151(13.2)$ & $74,970(13.0)$ & $76,465(12.9)$ & $74,722(13.0)$ \\
\hline Land use & $24,710(4.5)$ & $24,710(4.3)$ & $24,710(4.2)$ & $24,710(4.3)$ \\
\hline IOC (10\%) & $47,441(8.7)$ & $50,260(8.7)$ & $51,755(8.7)$ & $50,012(8.7)$ \\
\hline Total cost (A+B) & $546,558(100)$ & $577,572(100)$ & $594,016(100)$ & $574,841(100)$ \\
\hline
\end{tabular}

Note: Figures in the parenthesis indicates respective percentages.

\section{Profitability offloating gardening}

Floating gardeners mainly cultivate different types of vegetables like red-amaranth, lady's finger, cabbage, bottle gourd, papaya, chili and vegetable seedlings etc. (Pavel et al., 2014; Kabir et al. 2019). The main source of income of this cultivation is the return from these produces. Yearly average gross return of this gardening was BDT 1,032,742 per hectare (Table 4). Study also reveals that the yearly average total variable cost and total cost of floating gardening in the study area as BDT 500,118 and BDT 574,841 per hectare. Thus, the gross margin and net return of the practice were BDT 532,624 and BDT 457,901 per hectare (Table 4). Requirement of lower fixed costs for floating gardening were the reason for lower difference between gross margin and net return of this practice. Among different groups of farmer, marginal farmers reap higher gross and net return from this practice. Better management possibilities of smaller farm and greater devotion to income generation from this practice might be the reason behind their higher income generating capacity. Overall benefit cost ratio (BCR) was 1.80 , which was higher than that of land-based agriculture (Islam and Atkins, 2007; Hoque et al., 2016). Islam et al. (2015a) also found a range of BCR from 1.6 to 2.6 for different floating vegetable cultivation in some southern districts of Bangladesh. For this higher income generating capacity, landless or marginal people of wetland areas tend to start floating gardening with a lower capital in their hands. This income earning agricultural activity helps the farmers to manage their livelihoods even in adverse situations. Thus, the result indicates the importance of this practice as an alternative source of income that may contribute to ensure food security for the respondent farmers. 
Table 4. Profitability analysis of floating gardening (yearly per hectare).

\begin{tabular}{|lccccc|}
\hline Particulars & Formula & $\begin{array}{c}\text { Marginal } \\
\text { farmer }\end{array}$ & $\begin{array}{c}\text { Small } \\
\text { farmer }\end{array}$ & $\begin{array}{c}\text { Medium } \\
\text { farmer }\end{array}$ & Average \\
\hline Gross return (BDT) & GR & $\mathbf{1 , 0 4 8 , 9 4 0}$ & $\mathbf{1 , 0 2 0 , 5 2 3}$ & $\mathbf{1 , 0 4 7 , 7 0 4}$ & $1,032,742$ \\
\hline Total variable cost (BDT) & TVC & 474,407 & 502,601 & 517,551 & 500,118 \\
\hline Total cost (BDT) & TC & 546,558 & 577,572 & 594,016 & 574,841 \\
\hline Gross margin (BDT) & GR-TVC & 574,532 & 517,922 & 530,153 & 532,624 \\
\hline Net Return (BDT) & GR-TC & 502,381 & 442,951 & 453,688 & 457,901 \\
\hline Benefit cost ratio (BCR) & GR $\div$ TC & 1.92 & 1.77 & 1.76 & 1.80 \\
\hline
\end{tabular}

Factors affecting the yield of floating gardening

The value of $\mathrm{R}^{2}$ of the model (o.69) indicates that about sixty-nine percent of the variation in yield of floating gardening was explained by the explanatory variables included in the model. Significant F-value $\left(19.76^{* * *}\right)$ implying that all the independent variables included in the model were important for explaining the variations of yield.

Cobb-Douglas production function was used to assess the factors influencing the yield of floating gardening. The estimated values of the coefficient and their related statistics have been presented in Table 5. Coefficient of human labour, fertilizers and support materials were positive and significant at $1 \%$ level. The coefficient of insecticides \& pesticides was positive and significant at $5 \%$ level. The results imply that on an average, $10 \%$ increase in human labour, fertilizers, insecticides \& pesticides and support materials, remaining other factors constant, would increase the yield of floating gardening by $0.10,0.43,0.57$ and 0.54 percent, respectively. Achieving optimality might be the reason behind the smaller increase in yield with the incremental use of human labour in this practice.

Table 5. Estimated coefficients and their related statistics of production function for floating gardening.

\begin{tabular}{|lccc|}
\hline Explanatory variables & Parameters & Co-efficient & t-value \\
\hline Intercept & $\beta_{\mathrm{o}}$ & $12.640^{* * * *}$ & 3.38 \\
\hline Human labour $\left(\mathrm{X}_{1}\right)$ & $\beta_{1}$ & $0.010^{* * *}$ & 4.05 \\
\hline Seed or Seedling $\left(\mathrm{X}_{2}\right)$ & $\beta_{2}$ & 0.001 & 0.65 \\
\hline Fertilizers $\left(\mathrm{X}_{3}\right)$ & $\beta_{3}$ & $0.043^{* * *}$ & 2.62 \\
\hline Insecticides \& Pesticides $\left(\mathrm{X}_{4}\right)$ & $\beta_{4}$ & $0.057^{* *}$ & 2.45 \\
\hline Support materials $\left(\mathrm{X}_{5}\right)$ & $\beta_{5}$ & $0.054^{* * *}$ & 3.58 \\
\hline $\mathrm{R}^{2}$ & & 0.690 & \\
\hline F-value & & $19.76^{* * *}$ & \\
\hline
\end{tabular}

Note: ${ }^{* * *}$ and ${ }^{* *}$ indicate significant at $1 \%$ and $5 \%$ level.

Problems encountered by the floating problems associated with this practice has been gardeners

presented in Table 6. The entire problems mentioned by the gardeners were recorded and

To identify the constraints encountered by the floating gardener of the study area, gardeners were asked to mention the problems they faced during their cultivation practices. A detail of the grouped into economic, technical and marketing categories and ranked based on their frequency of mentioning.

Table 6. Problem encountered by the floating gardeners.

\begin{tabular}{|c|c|c|}
\hline Name of the problem & $\begin{array}{l}\text { Faced by the \% of } \\
\text { floating gardener }\end{array}$ & Rank \\
\hline \multicolumn{3}{|l|}{ Economic problem } \\
\hline Lower farm gate price & 44 & 1 \\
\hline Higher input price & 19 & 5 \\
\hline \multicolumn{3}{|l|}{ Technical problem } \\
\hline Lack of scientific knowledge & 39 & 3 \\
\hline Pest infestation & 27 & 4 \\
\hline \multicolumn{3}{|l|}{ Marketing problem } \\
\hline Poor bargaining capacity & 41 & 2 \\
\hline Transportation problem & 18 & 6 \\
\hline
\end{tabular}


Lower farm gate price, poor bargaining capacity, lack of scientific knowledge, insufficient credit facilities, pest infestation and higher input price were the mostly mentioned problems. Unfavourable economic condition of the floating gardeners might be responsible for their poor bargaining capacity as well as having lower farm gate price of their produces. Hasan et al. (2017) and Islam et al. (2019) also identified the shortage of technical knowledge as the most encountered problem in floating gardening and suggested for arranging more training to overcome the problems.

\section{Conclusions}

Floating gardening was profitable and mostly adopted by small and marginal farmers to fight against the harsh effect of climate change. Moreover, it can serve as an income generating activity in wetlands. Sensible use of human labour, fertilizers and support materials can further increase that income. Additional arrangement of training and smooth vegetable marketing system could be some crucial measures for further development.

\section{References}

Ahmed, A.U. 2006. Bangladesh climate change impacts and vulnerability: A synthesis. In: Comprehensive Disaster Management Programme, Climate Change Cell, Department of Environment, Government of the People's Republic of Bangladesh. 42p.

Alam, K. and Chowdhury, M.A.T. 2018. Floating Vegetable Gardening (FVG) as a Sustainable Agricultural System in Bangladesh: Prospects for Kaptai Lake, Rangamati, Chittagong Hill-Tracts. OIDA Int. J. Sust. Dev. 11(3): 43-58.

Awal, M.A. 2014. Water logging in southwestern coastal region of Bangladesh: Local adaptation and policy options. Science Postprint. 1(1): eooo38.

https://doi.org/10.14340/spp.2014.12A0001

Beattie, B.R. and Taylor, C.R. 1985. The Economics of Production. Montana State University, John Wiley and Sons, New York, USA. pp. 179-222.

Brouwer, R., Akter, S., Brander, L. and Haque, E. 2007. Socioeconomic vulnerability and adaptation to environmental risk: A case study of climate change and flooding in Bangladesh. Risk Anal. 7: 313-326. https://doi.org/10.1111/j.1539-6924.2007.00884.x

Byomkesh, T., Nakagoshi, N. and Shahedu, M.R. 2008. State and Management of Wetlands in Bangladesh, Landscape Ecol. Eng. 5: 81. https://doi.org/10.1007/s11355-008-0052-5

Chowdhury, R.B. and Moore, G.A. 2017. Floating agriculture: A potential cleaner production technique for climate change adaptation and sustainable community development in Bangladesh. J. Cleaner Prod. 150: 371-389. https://doi.org/10.1016/j.jclepro.2015.10.060

DAE. 1999. Agricultural Extension Manual. Department of Agricultural Extension, Ministry of Agriculture. Government of the People's Republic of Bangladesh. 11p.

Haq, A.H.M.R. and Nawaz, K.W. 2009. Soil-less agriculture gains ground. LEISA. 25: 34-35.

Hasan, S.S., Mohammad, A., Ghosh, M.K. and Khalil, M.I. 2017. Assessing of farmers' opinion towards floating agriculture as a means of cleaner production: A case of Barisal district, Bangladesh. British J. Appl. Sci. Tech. 20(6): 1-14. https://doi.org/10.9734/BJAST/2017/33635

Heady, E.O. and Dillon, J.L. 1961. Agricultural production functions. Iowa State University Press, Ames. 8p.

Hoque, M.Z., Haque, M.E., Afrad, M.S.I. and Islam, M.N. 2016. Effectiveness of floating agriculture for adapting climate change in southern Bangladesh. Int. J. Econ. Theory Appl. 3(1): 14-25.

Irfanullah, H.M. 2009. Floating gardening in Bangladesh: Already affected by climate variability? pp. 7-14. In: Biodiversity conservation and response to climate variability at community level, IUCN, UNEP, UNU, Dhaka, Bangladesh.

Irfanullah, H.M. 2013. Floating gardening: A local lad becoming a climate celebrity? Clean Slate. 88: 26-27.

Irfanullah, H.M., Adrika, A., Ghani, A. and Khan, Z.A. 2007. Introduction of floating gardening in the north-eastern wetlands of Bangladesh for nutritional security and sustainable livelihood. Renewable Agric. Food Syst. 23(2): 89-96.

https://doi.org/10.1017/S1742170507002074

Irfanullah, H.M., Azad, M.A.K., Kamruzzaman, M. and Wahed, M.A. 2011. Floating gardening in Bangladesh: A means to rebuild life after devastating flood. Indian J. Tradi. Knowl. 10(1): 31-38.

Islam, M.A., Kamruzzaman, M., Akter, A. and Roy, P.C. 2015a. Perception of Haor farmers about the innovative features of floating farming. Int. J. Nat. Soc. Sci. 2(4): 52-58. https://www.aascit.org/journal/archive2.

Islam, M.A., Khandoker, M.S.A. and Choudhury, S. 2019. Constraints of floating farming in haor area of Bangladesh. Int. J. Agril. Sci. 9(9): 001-005.

Islam, M.A., Shitangsu, P.K. and Hassan, M.Z. 2015b. Agricultural vulnerability in Bangladesh to climate change induced sea level rise and options for adaptation: a study of a coastal Upazila. J. Agric. Environ. Int. Dev. 109(1): 19-39.

https://doi.org/10.12895/jaeid.20151.218 
Islam, T. and Atkins, P. 2007. Indigenous Floating Cultivation: a Sustainable Agricultural Practice in the Wetlands of Bangladesh. Dev. in Prac. 4(1): 130-136. https://doi.org/10.1080/09614520601092733

IUCN. 2008. Bangladesh Baira: The Floating Garden for Sustainable Livelihood. www.apan-gan.net > Projects.

Kabir, A., Hasan, M.M., Ahmed, B. and Islam, S. 2020. Climate change perception and adaptation strategies of southwest coastal Bangladesh. American Sci. Res. J. Eng. Tech. Sci. 66(1): 47-68.

Kabir, M.A., Moniruzzaman, M., Jahan, K. and Shahjahan, M. 2019. Cost-benefit analysis of seedling production on floating beds in a few selected areas of Bangladesh. J. Agril. Stud. 7(2): 75-86. https://doi.org/10.5296/jas.v7i2.14788

MoEF. 2005. National Adaptation Programme of Action (NAPA). Final Report, Ministry of Environment and Forest (MoEF), Government of the People's Republic of Bangladesh. 38p.

Pavel, M.A., Chowdhury, M.A. and Mamun, M.M.A. 2014. An economic evaluation of the floating garden as a means of adapting to climate change in Bangladesh. Int. J. Environ. Stud. 71(3): 261-269.

https://doi.org/10.1080/00207233.2014.911406
Pavel, M.A.A., Khan, M.A.S.A., Rahman, S.A. and Mamun, M.A.A. 2013. Climate change adaptation strategy for the folk communities: An approach to vegetable production in flood prone areas. Int. J. Agron. Plant Prod. 4: $745-752$.

Saha, S.K. 2010. Soilless cultivation for landless people: An alternative livelihood practice through indigenous hydroponic agriculture in flood-prone Bangladesh. Ritsumeikan $J$. Asia Pacific Stud. 27: 139-152. Retrieved at www.apu.ac.jp/rcaps/uploads/fckeditor/.../RJAP S_V27_Saha.pdf

Sen, S. and Zaid, F.A. 2010. Communities cope with flooding situation with Gaota. LEISA. 12: 22-23.

Sujan, H.K., Islam, F., Kazal, M.H. and Mondal, R.K. 2017a. Profitability and resource use efficiency of potato cultivation in Munshiganj district of Bangladesh. SAARC J. Agric. 15(2): 193-206. https://doi.org/10.3329/sja.v15i2.35151

Sujan, M.H.K., Islam, F., Azad, M.J. and Rayhan, S.J. 2017b. Financial profitability and resource use efficiency of boro rice cultivation in some selected area of Bangladesh. African J. Agric. Res. 12(29): 2404-2411. https://doi.org/10.5897/AJAR2017.12443

Winterborne, J. 2005. Hydroponics: Indoor Horticulture. Pukka Press Ltd., UK. 258p. 